\title{
REGULATION OF CORPORATE FINANCE AND MAN- AGEMENT UNDER THE PUBLIC UTILITY HOLDING COMPANY ACT OF I935*
}

$7 \mathrm{HE}$ most dynamic legislation of the New Deal affecting corpany Act of $1935^{1}$ Quite apart from its program of economic planning in which the "death sentence " provisions play so prominent a part, the Act provides a basis for realigning the legal principles of corporate practice. Already the SEC has interpreted both the letter and spirit of the Act so as to impose standards which proceed far beyond the principle of disclosure. Though confined in their application to the public utility industry, these standards have wider significance, for ultimately they may be applied to all corporate finance and management should proposed legislation be adopted. $^{2}$

The broad objective of the Act is to protect investors, consumers and the public in general from certain abusive practices in corporate finance and management. These practices were re-

* This article is based exclusively upon information derived from the published releases of the SEC up to and including Holding Company Act Release No. I30I, November 2, r938. Nothing herein may properly be taken as an expression of opinion of the Commission or any of its officials.

149 STAT. 803 (1935), I5 U. S. C. $\$ 79$ (Supp. r937), hereafter referred to simply as "the Act" unless the full title is necessary for clarity.

2 Several bills introduced in the 75th Congress afford opportunities for applying standards developed under the Public Utility Holding Company Act to corporations outside the public utility field. The Lea Bill, H. R. 6968, subjects to administrative supervision the solicitation of proxies, deposits and assents in reorganizations, voluntary readjustments, and debt arrangements of all types of corporations. The Barkley Bill, S. 2344, aims to impose true fiduciary duties on trustees under indentures. The Borah-O'Mahoney Bill, S. 3072, providing for federal licensing of corporations in interstate commerce, restricts the power of a corporation to hold stock in another corporation and seeks to eliminate nonvoting stocks.

Further legislation utilizing these standards may result from the report of the Joint Congressional-Executive Committee engaged in investigating monopoly and concentration of economic power. The function of the SEC in this investigation is to report on corporate finance and corporate structures, including the advisability and feasibility of federal incorporation or licensing of corporations engaged in interstate commerce. 
garded as particularly objectionable in the public utility field where corporate structures and securities had attained a high degree of complexity. ${ }^{3}$ The Act proposes to eliminate some of these practices and modify others by a comprehensive program of simplification which is designed to narrow the gap between ownership and management and affects the securities of the individual company, its corporate structure, and the set-up of the holding company system to which it belongs.

Our purpose here is to examine the record of the Commission during the three years it has been administering the Act to ascertain what standards have been adopted and how they have been imposed. ${ }^{*}$ While at the present stage of administration the Commission's releases afford a very incomplete picture, it is possible to indicate the general direction in which the Commission is moving. ${ }^{5}$ The effect of the Act upon corporate finance and management can best be analyzed through the medium of two general questions. First, what has been its impact upon securities issued and upon the corporate structure both of individual companies and of holding company systems? Second, to what extent has the Act tended to impose new concepts of fiduciary responsibility upon those participating in corporate finance and management?

\section{Corporate Structures, Securities and Their Provisions}

Sections 6 and 7 of the Act together provide the cornerstone in the process of achieving simplification of the structure of individual companies and their securities. Section 6(a), as the prel-

3 For a general survey of the public utility industry, see FED. Trade CoM. Report on the Economic, Financial and Corporate Phases of Holding and Operating Companies of Electric and Gas UtilitIES, Sen. Doc. No. 92, 7oth Cong., Ist Sess. (r935) pt. 72A, cc. 4, 6, referred to hereinafter as UTwity Corporations. See also Berle and Means, The Modern Corporation and Private Property (I932), particularly bk. I, cc. V, VI, and bk. II, cc. I, II, IV-VI.

4 Limitations of space prevent consideration of certain important aspects of the Commission's administration of the Act. The creation of new standards in the field of accounting and dividends will not be discussed. Also excluded are problems of exemptions under $\S \S 2,3$ and $6(\mathrm{~b})$, though some reference will be made to one phase of the last-named section.

5 The problems of integration of public utility systems have not as yet been dealt with by the Commission in a manner comprehensive enough to warrant present discussion. See pp. 232-33, infra. 
ude to Section 7, declares the issuance of securities and the alteration of certain rights of holders of outstanding securities to be unlawful, except upon compliance with Section 7 . This latter section sets forth standards for determining both the proper corporate structure of a company and the nature of the securities which may go to make up that structure. At the same time subsection (b) of Section 6 permits certain exemptions from Section 7 , of which perhaps the most important is the issuance by an operating company of securities for the purpose of financing its business when authorized by the commission of the state in which the company is organized and doing business. ${ }^{\circ}$ The Commission, however, may attach to the granting of these exemptions "such terms and conditions as it deems appropriate in the public interest or for the protection of investors or consumers." Thus even though the Act does purport to make a distinction between holding companies and operating companies, for all practical purposes the Commission is in a position to require of both substantial compliance with the standards of Section 7 and in this way to make the exemption illusory. That such may be the policy of the Commission on occasion is indicated in several recent cases. ${ }^{7}$

6 This provision seems to have been a compromise between the Senate and the House. In the Senate bill prior to the conference report, $\$ 6(a)$ applied to any registered holding company and any subsidiary thereof, while in the House bill it applied to any registered holding company and to any subsidiary thereof which was a public utility company, the issuance of whose securities was not subject to regulation by a state commission. The point of view of the House apparently was that the Act should not apply where a state commission was in a position to remedy the abuses. See 79 Cong. Rec. I4619 (I935).

3 For example, in American Light \& Traction Company, Holding Company Act Release No. 1272 , October 14 , I938, an application was made for exemption under $\S 6(\mathrm{~b})$ of the issue and sale of certain bonds and notes. The applicant was organized and doing business in Michigan, the issue and sale were solely for the purpose of financing its business, and approval of the Michigan Public Utilities Commission had been obtained. However, persons controlling the underwriters of the securities were also interested indirectly as stockholders in the applicant. Accordingly, the Commission made a detailed examination of the underwriting arrangements and made sure that the prices at which the bonds and notes were sold to the underwriters were fair and that the underwriters' spreads were reasonable. If the Commission had not been satisfied on these two points presumably the exemption would still have been granted, but subject to conditions as to the prices and the spreads. The applicant was able to bring itself within the express language of the exemptive provision of $\S 6(\mathrm{~b})$, but nevertheless the Commission followed a procedure of investigation identical with that employed in passing on issues and sales of securities under $\$ 7$. See cases discussed at pp. 238-4r, infra. 
The fundamental tests with respect to the issuance of securities are found in subsections (c) (I) and (c) (2) of Section 7. A brief résumé of their provisions is helpful in providing a general background.

The ideal corporate structure contemplated by subsection (c) (I) appears to be one class of stock and one class of bonds. In the case of stock the type desired is " a common stock having a par value and being without preference as to dividends or distribution over, and having at least equal voting rights with, any outstanding security of the declarant." For a bond to qualify it must be secured by a first lien on physical property of the declarant, or by an obligation of a subsidiary of the declarant which is secured by a first lien on physical property of the subsidiary, or by any other assets of the type and character which the Commission may prescribe " as appropriate in the public interest or for the protection of investors." Thus both the ideal corporate structure and the ideal types of securities are in accord with the Act's dominant theme of simplicity.

These standards of subsection (c) (I) are deprived of much of their significance by the alternative provisions of subsection (c) (2). Without requiring compliance with any of them, the Commission, under paragraph (A) of the latter subsection, may permit a holding company or an operating company to issue securities as part of a refunding or exchange operation. ${ }^{8}$ Under

Other examples where the Commission has granted exemptions subject to conditions are Cumberland County Light \& Power Company, Holding Company Act Release No. Ior6, March 3, 1938; Toledo Edison Company, Holding Company Act Release No. 1206, August 16 , x938; Virginia Electric and Power Company, Holding Company Act Release No. r262, October 5, I938; Michigan Consolidated Gas Company, Holding Company Act Release No. 1263, October 6, 1938; Virginia Public Service Company, Holding Company Act Release No. 1296, October 3r, r938. See also Indiana General Service Company, Holding Company Act Release No. 126r, October 5, I938, discussed at p. 256, infra.

While this policy of the Commission would seem to be contrary to the intent of the House conferees in agreeing to the Senate version of $\S 6(\mathrm{a})$, it does not conflict with the literal language of the clause. However, there does seem to be no justification for subjecting an issue and sale of securities to the surveillance of two commissions, one state and the other federal, with the attendant unnecessary expenses.

8 Section $\eta(c)(2)(A)$ provides that the Commission must find that the securities are to be issued or sold solely " for the purpose of refunding, extending, exchanging, or discharging an outstanding security of the declarant and/or a predecessor company thereof or for the purpose of effecting a merger, consolidation, or other reorganization." 
paragraph (B) similar treatment is provided for securities of an operating company issued for the purpose of financing its business. ${ }^{9}$ Consequently the principal effect of the standards of subsection (c) (I) is on securities of a holding company issued to raise funds for holding company purposes. ${ }^{10}$ But even here paragraph (D) of subsection (c) (2) permits the Commission to relieve a declarant from compliance with subsection (c) (I) where the issue is "for necessary and urgent corporate purposes" and where the requirements of subsection (c) (I) "would impose an unreasonable financial burden upon the declarant and are not necessary or appropriate in the public interest or for the protection of investors or consumers."

The record of public utility financing from I935 through 1938 bears out the conclusion that as yet subsection (c)( $I$ ) has had little significance. Nearly all the declarations regarding new issues have become effective under subsection (c)(2), principally because most of such financing has been refunding in nature and falls within the express terms of paragraph (A). Furthermore, the capital market has been unreceptive to new security issues of public utility holding companies, to which subsection (c) (I) particularly applies. ${ }^{11}$ Nevertheless, subsection (c)(I) remains the ultimate goal to be attained and the Commission is not likely to lose sight of it in passing on security issues under the supplemental authority of subsection (d) of Section $7 .{ }^{12}$

- Section 7 (c) (2) (B) provides that the Commission must find that the securities are to be issued or sold solely " for the purpose of financing the business of the declarant as a public utility company."

10 Subsection (c) ( $I$ ) is aimed at new issues of holding company securities for holding company purposes, for such issues were felt to be subject to the most frequent abuse. But issues of securities by subsidiary and operating companies for operating purposes, or to use the language of the Act, "public utility " purposes [see $\S 2(a)(3)-(5)]$, are not so restricted and any type of security can be issued which complies with $\S \eta(\mathrm{d})$.

11 In addition to general causes, two factors in particular seem to have been responsible for this state of the capital market. One has been the Act itself, for with enforcement of $\S \mathrm{II}$ in the offing, there was little inclination to buy holding company securities. The other has been the threat of government competition in the operating field, upon which the holding company necessarily depends for its life blood. This threat also has adversely affected the market for "equity capital " for operating companies. See Bonbright, Public Ownership and National Power Policy (I938) 28 YALE REVIEW 36.

12 See Address of Abe Fortas, Esq., Assistant Director of the Public Utilities 
Subsections (d) and (e) of Section 7 , relating respectively to the issue of securities and to alteration of rights of existing security holders, prescribe general rather than specific tests. Consequently, they are all the more readily available as vehicles for the imposition of standards. Couched in negative terms, these subsections permit a declaration to become effective unless the Commission makes adverse findings on the basis of specified general criteria, the broadest of which is whether such declaration has results detrimental to the public interest or the interests of investors or consumers. ${ }^{13}$

Of the many releases of the Commission, by far the greater proportion have been routine in nature and do not merit comment. But a few contain indications that imposition of standards by the Commission is bringing about some changes in corporate finance and management. It is in these that the impact of the Act on corporate structures and securities is to be discerned.

No-par Stock. The use of no-par stock, and to a lesser degree that of low-par shares, has often been cited as a responsible factor in facilitating the spectacular public utility promotions of the predepression era. The power of corporate directors to allocate the consideration received upon the issuance of no-par stock in part to surplus, and the elasticity of price in the case of low-par shares

Division of the SEC, before the practicing law courses held in New York City, October 27, 1938 . Copies of this address have been released by the Commission.

13 Subsection (d) specifically provides: "If the requirements of subsections (c) and $(\mathrm{g})$ [the latter referring to failure to comply with state laws] are satisfied, the Commission shall permit a declaration regarding the issue or sale of a security to become effective unless the Commission finds that -

(I) the security is not reasonably adapted to the security structure of the declarant and other companies in the same holding-company system;

(2) the security is not reasonably adapted to the earning power of the declarant;

(3) financing by the issue and sale of the particular security is not necessary or appropriate to the economical and efficient operation of a business in which the applicant lawfully is engaged or has an interest;

(4) the fees, commissions, or other remuneration, to whomsoever paid, directly or indirectly, in connection with the issue, sale, or distribution of the security are not reasonable;

(5) in the case of a security that is a guaranty of, or assumption of liability on, a security of another company, the circumstances are such as to constitute the making of such guaranty or the assumption of such liability an improper risk for the declarant; or

(6) the terms and conditions of the issue or sale of the security are detrimental to the public interest or the interest of investors or consumers." 
made it easier to create an initial surplus available for dividends. The danger of permitting dividends to be paid from such a surplus has been a major criticism of both types of stock. ${ }^{14}$

The Act is sufficiently comprehensive to permit the Commission to control both no-par and low-par shares. The no-par device is specifically excluded from the approved type of common stock in subsection (c) (I) of Section 7, so despite the infrequent application of the subsection, such exclusion would establish a heavy presumption against its issuance in any case..$^{15}$ Apart from this presumption, the Commission derives broad authority from other sections of the Act to eliminate any abuse of either no-par or low-par shares. Under subsections (d) and (e) of Section 7 , a wrongful allocation to surplus could be held "detrimental to the public interest or the interest of investors or consumers." Furthermore the Commission has control over dividend declarations and accounting practices under Sections I2(c) and I5.

Of the two types of shares, no-par stock has figured more prominently in the opinions of the Commission. Like so many other practices, no-par stock is not per se harmful. Its evils lie in the way it has been used. Since the various elements responsible for these evils can be controlled under the general authority of the Commission, and since no-par stock can become a useful instrument under many circumstances, no necessity appears for a rigid rule prohibiting its issuance altogether.

This principle the Commission happily has recognized in several cases and the issuance of no-par shares has been permitted. The value of the device and the manner in which the Commission has subjected it to control is well illustrated in the case of National Gas and Electric Corporation. ${ }^{16}$ The declarant was seeking to amend its certificate of incorporation to change its existing \$Io

14 The use of no-par shares in the public utility field is described in UTIIITY CoRporations, pt. $72 \mathrm{~A}$, c. 6, pp. 389-94. For discussion of the various problems arising in connection with the use of such shares, see Bonbright, The Dangers of Shares Without Par Value (r924) 24 Col. L. REv. 449; BERLE, STUdIES IN THE LAW of Corporation Finance (I928) c. 4; Weiner, The Amount Available for Dividends Where No-Par Shares Have Been Issued (I929) 29 Cor. L. REv. g06; Ballantine, Nonpar Stock - Its Use and Abuse (I923) 57 Ax. L. REv. 233; Note (I937) 37 COL. L. REv. $936,972$.

15 See National Gas \& Electric Corporation, Holding Company Act Release No. 768, August 4, x937, p. 7.

16 Holding Company Act Release No. 768, August 4, 1937. 
par common stock to no-par common and to issue additional shares of such stock. The case was complicated by two existing transactions. First, the declarant wished to purchase certain gas properties from another company in return for shares of its common stock, which the vendor gas company had agreed to take at $\$ 7.50$ per share. The Commission found that the acquisition of these gas properties by the declarant was for a " necessary and urgent" corporate purpose. Secondly, the declarant was obligated to purchase the assets of another company which was being reorganized under former Section $77 \mathrm{~B}$ of the Bankruptcy Act. The plan of reorganization called for the exchange of such assets for declarant's \$Io par value common stock. Since the existing common stock could not be issued for the gas properties at less than par, there were three possible alternatives. A second class of common stock of $\$ 7.50$ par value could be created; the par value of the existing common could be reduced to $\$ 7.50$; or the existing common could be changed to a no-par stock. The Commission without hesitation rejected the first alternative as wholly undesirable. As to the second the declarant argued that the reduction would create a surplus which might be detrimental to its selling certain bonds which it planned to issue, as well as harming its credit in general. Moreover, it argued, to change the stock to $\$ 7.50$ par would require resubmission of the plan of reorganization of the company in Section $77^{B}$ which was selling its assets to declarant, for such a reduction would constitute a material change. But the change to no-par stock would not require such resubmission since the value at which the no-par stock was to be carried on declarant's books was the equivalent of $\$$ IO and hence the change was not a material one. The declarant also stated that it proposed to capitalize the entire amount received for the no-par shares.

Confronted with this situation the Commission approved the issue. It found that since no part of the consideration received for the shares would be allocated to surplus and in view of the restrictions imposed by the Act as a whole, the no-par shares were the practical equivalent of par shares. In view of this the Commission felt the declarant had met the burden of clause (D) of subsection (c) (2) and shown that compliance with subsection (c) (I) was neither necessary nor appropriate. Thus no-par stock was utilized in such a way as to benefit all persons concerned, and 
it was demonstrated that by imposing proper safeguards no blanket prohibition of its use was necessary. ${ }^{17}$

Distribution of Voting Power Among Stockholders. In the "ideal" corporate structure suggested in subsection (c)(I) of Section 7 , one standard prescribed for any stock issue is that its voting power shall be at least equal to that of any outstanding security of the declarant. This is a direct attack on the frequent provisions of the twenties whereby the stockholder either was deprived entirely of a right to vote or that right was seriously restricted. Unlike the no-par stock question discussed above, voting power, once defined, is a matter which the Commission cannot supervise properly by curbing its collateral abuses. The evil, if any, lies in the control exercised by persons having a negligible investment in the company, which in turn leads to inadequate representation of those parties who have the most substantial investment in the enterprise.

In addition to Section 7 (c) (I), which at present has little pragmatic significance, the Commission derives authority from other provisions of the Act to enforce the principle of equal distribution of voting power. Section 7 (d)(6) enables the Commission to pass upon the terms and conditions of the issue or sale of any security, and Section 7 (e) expressly empowers it to prevent any alteration in voting rights of existing stockholders if such alteration results in an unfair and inequitable distribution of voting power. Moreover, Section II (b) (2) contains a similar phrase in requiring the Commission to ensure that the corporate structure of any company in a system does not unfairly or inequitably distribute voting power. In regard to common stock the principal significance of these provisions up to the present time has been in reorganizations with reference to its distribution under the plan. Since in such situations the problem of voting power usually is only one element of the larger problem of the fairness of the plan, it will be reserved for consideration later herein in that connection. ${ }^{18}$

17 The Commission has permitted the issuance of no-par stock in other instances. See General Public Utilities, Inc., Holding Company Act Release No. 889, November I9, I937 (dividend payable in cash or fractional shares of no-par stock, at stockholders option, to avoid tax on undistributed profits); Lone Star Gas Corporation, Holding Company Act Release No. I244, September r9, I938 (delay incident to authorization of par value common stock by stockholders would endanger possibility of effecting the contemplated financing).

18 See p. 247 et seq., infra. 
The importance of distribution of voting power is not confined to common stocks. In the past many preferred issues had no vote whatever or a voting power contingent upon default in certain dividend payments. Often this contingent voting power was illusory, either because the conditions upon which the contingency was to occur were exceedingly remote or because even when such voting power did come into existence it was insufficient to overcome a preponderant vote of the common stock.

Already the Commission has given definite indication that this situation cannot continue and that preferred stocks must be given substantial voting rights. In American Waterworks \& Electric Co. ${ }^{19}$ preferred stocks of various companies in the system had voting rights contingent upon default in dividend payments, but upon the happening of the contingency the preferred shares only voted share for share with the common shares. In some companies the shares of common stock in proportion to the amount of investment represented thereby was greatly in excess of the number of shares of preferred so that the voting rights of the preferred were likely to be ineffective. Consequently, the Commission said "that such distribution of voting power falls short of being fair and equitable." But because the companies in the system had long uninterrupted records of dividend payments on their preferred stocks, and since there seemed to be substantial common stock equities in the companies, the Commission decided not to require any change in the distribution of voting power prior to default in dividend payments. On the other hand it did state that it expected changes to be made to give more adequate protection in the event of default in payment of preferred dividends. ${ }^{20}$ At the same time the Commission made clear that a distinction would be drawn in respect to requiring changes in distribution in voting power between outstanding preferred stocks and new preferred

19 Holding Company Act Release No. 949, December 30, 1937. The case came before the Commission through the submission of a voluntary plan under $\S \mathrm{II}(\mathrm{e})$ to meet the simplification requirements of $\S \mathrm{II}(\mathrm{b})$.

20 See also International Paper and Power Company, Holding Company Act Release No. 642, May 5, I937, particularly the concurring opinion of Commissioner Douglas (now Chairman), together with his dissenting opinion in International Paper and Power Company, Holding Company Act Release No. 770, August 3, I937; Republic Electric Power Corporation, Holding Company Act Release No. I270, October $x_{3}, x_{93} 8$. 
stocks. In the latter case if the preferred stock investment was substantial it would expect the preferred stockholders to be given an effective voice in the management even prior to default.

Voting Trusts. Related to the problem of distribution of voting power is the position of the voting trust under the Act. This device found frequent use in the public utility field for many varied purposes. ${ }^{21}$ While less open to criticism than some of the other devices which divorce control of corporate affairs from ownership, nevertheless the voting trust has been attacked on that ground. ${ }^{22}$ Under the Act it obviously conflicts with the objective of restoring some measure of control to those having a substantial interest in the enterprise. Moreover, the creation of a voting trust may tend to complicate the structure of a holding company system and therein conflict with the simplification provisions of Section II (b) (2).

In view of these objections one might expect to find the voting trust little favored by the Commission. But since the principle behind the simplification theory is the elimination of structures which have no function in the operation of the system, it is clear that exceptions must be made in the case of voting trusts which fulfill an actual need. This need is demonstrated most frequently in reorganizations, where often plans have provided for such a voting trust to assure the new management sufficient tenure in office to prove its competence, or to assure bondholders of some control during the gestation period of the new company.

When confronted with situations involving these practical considerations, the Commission has sanctioned the use of the voting trust, and as in the case of no-par stock, has recognized that in proper cases it may be a highly effective means of accomplishing objectives otherwise attainable only with great difficulty. In the case of United Telephone \& Electric Company ${ }^{23}$ the Commis-

21 Two examples of the use of the voting trust as a control device existed in the Middle West Utilities System prior to its collapse. See UtIlITY Corporarions, pt. 72A, pp. 146, 405 et seq.; pt. 67, p. 714.

22 Berle and Means, The Modern Corporation and Private Property (I932) at 78, suggest that control through the voting trust device is less of an abuse because " it is fixed, defined, and inalienable, with certain definite and well recognized responsibilities attached."

${ }^{23}$ Holding Company Act Release No. II87, August 5, I938. See also the report of the Commission on the plan of reorganization, Holding Company Act Release No. II93, August 5, 1938 . 
sion's approval of a plan of reorganization was sought under Section $I I(f)$ of the Act. The plan allotted debentures to creditors of the old company and new common stock to the old preferred and common stockholders. Of this new common stock the old preferred stockholders were to receive 97.18 per cent, and as a result would have complete control of the corporation. However, under the reorganization plan the new common was to be placed in a voting trust to be held by five trustees for five years. At the end of three of the five years a referendum was to be held among the voting trust certificate holders to determine whether the voting trust should be continued for the remaining two years. Three of the five voting trustees had no financial interest whatever in the new company. The powers of the voting trustees included the sole power to elect directors, but on matters such as a sale or mortgage of all the corporate assets, changes in capital structure and changes in the number of directors, consent of a majority of the voting trust certificate holders was required.

The Commission at once voiced its objections to the plan on the ground that control was taken from the stockholders and given to trustees who had little or no interest in the company and that such divorcement of control from ownership was to last for five years. A second ground of criticism was that if a stockholder was unwilling to become a voting trust certificate holder, his only alternative was to vote to reject the plan of reorganization in its entirety and thus possibly force a continuation of the reorganization till another plan was proposed. On the other hand the Commission found certain factors which inclined it to favor the formation of some sort of voting trust. The former preferred stockholders who, without the voting trust, would be in control, were inexperienced voting stockholders. No person in the existing management was capable of acting as chief executive and no capable executive could be obtained elsewhere without some assurance of continuity in his position. With scattered stockholders, active proxy campaigns from time to time might make possible frequent shiftings in the management. But by means of the voting trust a reasonable degree of continuity could be promised to executives. Moreover, the creditors were insisting upon a voting trust, and this the Commission felt was entitled to great weight. Concluding that the need for a voting trust outweighed its possible evils, the 
Commission gave its approval conditioned on certain changes in the reorganization plan, including a provision whereby if the voting trust was not terminated by the referendum to be held at the end of three years, any voting trust certificate holder would be privileged to withdraw his stock from the voting trust. In addition the voting trustees were required to register as a holding company. With these safeguards the Commission felt the voting trust device had been confined to its proper function of carrying the new company through the initial difficult period of readjustment. ${ }^{24}$

The functional character of the voting trust in reorganizations was also recognized by the Commission in Great Lakes Utilities Company, ${ }^{25}$ where its use was accepted despite the criticism that it unduly complicated the structure of the holding company system. Here an intermediate holding company was in reorganization under former Section $77 \mathrm{~B}$ of the Bankruptcy Act. Under the plan of reorganization a new company was created which assumed the outstanding collateral trust bonds of the old company and issued new common stock to the former holders of the company's unsecured debt. Since over 98 per cent of such new common stock would go to the former parent of the old company, the holders of the collateral trust bonds requested the creation of a voting trust to hold the new common for the benefit of the new common stockholders. Nine voting trustees were to be named, six of whom were to represent the holders of collateral trust bonds. The term of the voting trust was limited to a maximum of five years, the ultimate date being that of the maturity of the outstanding collateral trust bonds. In approving the voting trust the Commission recognized that it would tend to complicate the corporate structure of the holding company system, but felt this would not be " undue" complication nor detrimental to the public interest

24 Use of a somewhat different device to carry a newly reorganized company through its first years was approved by the Commission in West Ohio Gas Company, Holding Company Act Release No. 1284 , October 22, 1938, involving a reorganization under former $\$ 77 \mathrm{~B}$ of the Bankruptcy Act. The initial board of directors was elected for a term of three years, thus assuring some stability in management for that period. Four of the seven directors so elected were to be chosen by the bondholders of the former company, two by the preferred stockholders and noteholders of the former company, and one by the bankruptcy court.

25 Holding Company Act Release No. 595, April 5, 1937. 
or that of investors and consumers because the term of the voting trust was definitely limited. The fact that the voting trust was created at the instance of creditors for their own protection also strongly influenced the Commission. Moreover, the voting trustees registered as a holding company thus subjecting themselves to some Commission supervision.

Many state legislatures have limited the permissible life of voting trusts to ten years. ${ }^{26}$ And legislatures and courts with a few exceptions have invariably sanctioned voting trusts created for protection of creditors. In its opinions the Commission has carried the former policy even further by imposing provisions which tend to reduce the effective life of the voting trust to considerably less than ten years. As to the latter policy the Commission seems impressed by the need for creditor control under certain circumstances and appears to be ready to sanction the voting trust device as a permissible means of exercising that control.

Pre-emptive Rights. The normal function of the pre-emptive right, entitling existing stockholders to subscribe to new issues, is said to be to protect their respective participations in assets, earnings and control. Created by judicial decision over a century ago, it soon became the common practice to eliminate this right by charter provision. More recently such charter provisions have been expressly sanctioned by statutory enactments. While there is considerable doubt as to whether a stockholder without a preemptive right is in any worse position legally than one with such a right, ${ }^{27}$ the fact remains that its elimination, especially when coupled with the device of maintaining large reservoirs of authorized but unissued shares, contributed materially to the success not only of desirable expansions in the public utility field but also of promotions of a speculative nature. These latter instances suggest one reason for the Commission to oppose attempts to eliminate the pre-emptive right in future issues. A second reason is its removal

${ }^{26}$ E.g., Ded. Rev. Code (I935) § 2050 (Del. Corp. LaW § I8); N. Y. StK. CoRp. LAW \& 50 .

27 That is, even without the pre-emptive right a stockholder is able to prevent the issuance of stock for an inadequate consideration. Likewise, he can have set aside an issue for the sole purpose of affecting control of the corporation. See Drinker, The Preëmptive Right of Shareholders to Subscribe to New Issues (1930) 43 HaRv. L. REv. 586; Frey, Shareholders' Pre-emptive Rights (I929) 38 YaLE L. J. 563. 
also may increase the difficulty of bridging the gap between management and ownership by preventing existing stockholders from maintaining their position in a company. At the same time it is clear that under certain circumstances the denial of the preemptive right may be justified on the purely practical ground of facilitating the financing process.

In striving to protect the interests of stockholders without unduly hampering financing, the Commission may be expected to propound its own standards of judgment under Sections $7(d)(6)$ and $\eta(e)$ as to whether the denial of the pre-emptive right in a particular case is " detrimental to the public interest or the interest of investors or consumers." ${ }^{28}$ Hence, it is no surprise to find the Commission disapproving the waiver of the pre-emptive right in Peoples Light \& Power Company ${ }^{29}$ and approving its retention in United Telephone \& Electric Company. ${ }^{30}$ But the most interesting commentary on the future of the pre-emptive right is in National Gas \& Electric Corporation. ${ }^{31}$ The proposed amendment to the certificate of incorporation, in addition to changing the \$ro par stock to no-par, also sought to remove the stockholders' pre-emptive right. The amendment was approved by an affirmative vote of 75 per cent of the holders of the voting trust certificates and the remaining 25 per cent did not dissent. While viewing with disapproval this method of securing approval of the amendment by capitalizing on the inertia of security holders, the Commission permitted the declaration to become effective under Section $7(\mathrm{e})$. But in its opinion the Commission made clear that its permission to sell the stock without first offering it to existing stockholders was confined to the immediate issue and that as to any future issues the Commission might require a prior offering to existing stockholders if it was deemed necessary to protect their interests in assets, earnings or voting power. Indeed, the Commission stated that as to future issues the burden would be on the declarant to establish that such a prior offering was not necessary or appropriate to protect the interests of existing stockholders.

The new stock in this case was being issued for property. It

28 This phrase appears in both $\$ \S 7(d)(6)$ and $\eta(e)$.

${ }^{29}$ Holding Company Act Release No. 885, November I6, 1937.

30 Holding Company Act Release No. II93, August 5, I938.

31 Holding Company Act Release No. 768, August 4, I937, discussed at pp. 222-23 supra, in connection with no-par stock. 
will be remembered that after having created the pre-emptive right, courts found it necessary for purely practical reasons to make an exception and hold that in such situations, despite the possibility of receipt of inadequate consideration, no pre-emptive right existed. While not so stated in the Commission's opinion, it seems to recognize the practical considerations upon which the property exception rests. From this it may be surmised that normally issues of stock for property will not be required to be first offered to existing stockholders, though the exception cannot be expected to solidify into a rule of practice of the Commission as it did into a rule of law in the courts. But even where such an issue is permitted the Commission will still pass on the value of the property and thus be able to prevent the issuance of stock for inadequate consideration with resultant injury to existing stockholders.

So far as issues of stock for cash are concerned the opinion in National Gas and Electric Company definitely rendered ineffective the elimination of the pre-emptive right. As a result, if the case is at all prophetic, it is entirely immaterial whether or not the certificate of incorporation of any public utility or holding company already has eliminated the pre-emptive right. Regardless of charter provisions, the Commission will act to afford what amounts to the pre-emptive right in situations where it is deemed necessary for the protection of existing stockholders against dilution of their interests. ${ }^{32}$

Holding Company System Structures. Just as Sections 6 and 7 afford the basis for simplifying the structure and securities of indi-

32 Under $\S \eta(d)(6)$, the most pertinent section on this point, the Commission's power extends to the "terms and conditions of the issue or sale" of a stock, and not to provisions of the stock itself. Accordingly, while the Commission may compel a prior offering to existing stockholders upon the issue or sale of a stock, seemingly it cannot compel the inclusion of the pre-emptive right in the stock. However, the Commission has implied that it has power to compel such an inclusion. In Republic Electric Power Corporation, Holding Company Act Release No. 1270, October I3, I938, involving voluntary reorganization under $\S \mathrm{II}(\mathrm{e})$, the new common stock to be issued was to have no pre-emptive right. Finding that the stockholders would be few in number and that a majority of the stock would be owned by a single stockholder, and because the company would still be under the supervision of state commissions, the Commission stated that "the inclusion of preemptive rights will not be insisted upon in this case." On the pre-emptive right generally, see also Washington Gas Light Company, Holding Company Act Release No. IIr7, June 9, r938. 
vidual companies, Section II is designed to simplify the structure of holding company systems. Its objective is twofold. First, to create geographically integrated systems whose business is confined to operating gas or electric properties. Second, to eliminate unnecessary complexity in the corporate structure of holding company systems and to distribute voting control among the security holders fairly and equitably. ${ }^{33}$

Up to the present time the Commission has been slow to enforce these simplification provisions. By its very terms Section $\mathrm{II}(\mathrm{b})$ did not become applicable until after January $I$, x 938 . The delay since that time is explained in part by the inadvisability of proceeding until the Supreme Court had established the constitutionality of the registration provisions of the Act in February, I938. ${ }^{34}$ But additional reasons for caution are apparent. The mere preparation of a plan for any major utility system requires time. The realignment of companies and properties within and between systems necessarily requires the redemption of old securities and the issuance of new, which in turn demands a brisk capital market. Moreover, the Commission wished to feel its way carefully, motivated perhaps by a desire to convert seemingly unworkable provisions of Section II into useful instruments for achieving the objectives of the Act as a whole. Thereby the establishment of embarrassing precedents has been avoided and simplification made an evolutionary rather than a revolutionary process. So it was quite natural for the Commission to adopt a policy of permitting companies to take the initiative in most cases by giving them leave until December I, I938, to file voluntary plans. The only case where it invoked Section II (b) involved a company undergoing reorganization under the Bankruptcy Act. ${ }^{35}$ Since some classes of security holders of the bankrupt had to accept a diminution of their interests, this case was a logical one for compelling a drastic overhauling of its structure and achieving integration of the system.

In view of the present formative stage of the interpretation of Section I ( (b), no attempt will be made to answer those imponder-

33 The first objective is provided for in $\S \mathrm{II}(\mathrm{b})(\mathrm{I})$; the second in $\S I I(b)$ (2).

34 Electric Bond \& Share Co. v. Securities and Exchange Comm., 303 U. S. 419 (I938).

35 Utilities Power and Light Corporation, Holding Company Act Release No. II67, July 20,1938 . 
ables which are the core of the integration program of subsection (b) (I).$^{38}$ These questions are of tremendous importance, but in three years, except for two cases, they remain almost completely unanswered. ${ }^{37}$ Even in the second phase of the simplification program under subsection (b) (2) it is only possible to point out problems which the Commission has had to face in eliminating companies which unnecessarily complicate the structure of holding company systems. Whether a system is already geographically integrated or not, this subsection limits such a structure to three tiers of companies, consisting of operating companies, first degree holding companies and a second degree or top holding company. This type of system structure, set forth as ideal in subsection (b) (2), the Commission has sought to accomplish not only directly under its provisions, but also in dealing with applications under other sections of the Act. ${ }^{38}$

A plan achieving this ideal system structure was approved by the Commission in American Water Works and Electric Company, where the top holding company submitted a voluntary plan under Section II (e)..$^{39}$ In respect of one subsidiary the top holding company was a fifth degree holding company; in respect of another a fourth degree relationship existed. The net result of the various procedural steps under the plan left a top holding com-

36 Among them are questions such as what is a "single integrated public-utility system"? What businesses "are reasonably incidental, or economically necessary or appropriate to the operation of such integrated public-utility system "? When is a system "so large as to impair the advantages of localized management, efficient operation, or the effectiveness of regulation "? How important to this decision will be the character of the region affected and the scientific development of long distance power transmission? The Act itself makes some attempt at definition. See $\$ \S 2$ (a) (29), II (b) (I) (A)-(C).

37 American Water Works and Electric Company, Holding Company Act Release No. 949, December 30, I937; Republic Electric Power Corporation, Holding Company Act Release No. I270, October $\mathrm{r}_{3}$, I938, stated in note 40, infra.

38 Under $\S \mathrm{I} I(f)$ dealing with plans of reorganization under court supervision, the Commission has had opportunities to clear the way for more complete simplification in the future. Under $\S \mathrm{Io}(\mathrm{c})(\mathrm{I})$, regarding the acquisition of securities and utility assets, approval of the Commission cannot be given if the acquisition is detrimental to carrying out $\S I I(b)$. Even in declarations under $\S 7$ the Commission has kept in mind the ultimate disposition of the particular system and its companies under $\S \mathrm{II}(\mathrm{b})$.

39 Holding Company Act Release No. 949, December 30, r937; Note (r938) 36 MiCH. L. REv. 1360; (I938) 38 CoL. L. REv. 928. 
pany, three subsidiary companies which were both operating and first degree holding companies, and finally a bottom tier of operating companies. Thus the system structure was simplified to a point where only one tier of companies intervened between the top holding company and the operating companies. ${ }^{40}$ But the accomplishment of this result was made possible only after a decision had been reached in regard to one of the Commission's troublesome problems under Section II(b), namely, the many traction interests of utility systems which it termed " in the nature of an inheritance from an earlier era " of the electric utility business. ${ }^{41}$ While the principal difficulties caused by the existence of traction interests usually are part of the problem of integration, in this instance it also imposed an impediment to achieving the desired structure of three tiers of companies. That adroit use of the exemptive provisions may provide an answer for this problem is demonstrated in West Penn Railways Company. ${ }^{42}$ A traction subsidiary of American Water Works and Electric Company owned 3 I per cent of the stock of West Penn Power Company. All the

40 The second integration case before the Commission has been resolved in a somewhat analogous fashion. In Republic Electric Power Corporation, Holding Company Act Release No. 1270 , October I3, 1938, the declarant owned properties scattered through Oklahoma, Oregon and California. Submitting a voluntary plan of simplification under $\S I I(e)$ and supplemental sections, the declarant proposed to dispose of its Oklahoma property, to merge all the Oregon and California companies into a single operating unit, and finally to dissolve itself as a holding company. Noting that some of the properties in the new operating unit were separated by long distances so that no single integrated system could exist, the Commission nevertheless approved the plan. In so doing the Commission knowingly surrendered jurisdiction over the new operating company, for being neither a holding company nor a subsidiary company, it would no longer fall within the terms of the Act.

The reasons assigned for failure to enforce the integration mandate of $\S \mathrm{II}(\mathrm{b})(\mathrm{x})$ were that the properties were largely isolated, their retention did not stand in the way of plans of integration of other systems, and they were small and could be managed more economically by a single operating company than as separate companies. Here the Commission clearly avoided the issue and left a group of properties which may never be integrated. There is some question whether or not it should be governed solely by the fact that the properties are small and hence of minor importance. Yet without additional facts it is impossible to determine whether or not these properties could have been integrated at all, even into other systems. The inference is that they could not. On this hypothesis control of the small isolated units by a single operating company appears to be a practical solution of a problem occasioned in large measure by the sweeping requirement of $\S \mathrm{rI}(\mathrm{b})(\mathrm{I})$ that all systems be integrated.

41 See Holding Company Act Release No. 949, December 30, I937, p. 12.

42 Holding Company Act Release No. 953, January 3, I938. 
remaining stock of West Penn Power Company was owned directly by American Water Works and Electric Company. If the traction company had been held to be a holding company and West Penn Power Company its subsidiary, there would have been four tiers of companies in the system and the requirements of Section II (b) (2) would not be satisfied. Accordingly the traction company applied for orders under Sections 2 (a) (7) and (8) declaring it not to be a holding company and declaring West Penn Power Company not to be its subsidiary.

Simplification by transferring the traction company's 3 I per cent stock interest to American Water Works and Electric Company would have raised a further problem. Such a transfer was practically impossible because it was the most valuable security for the traction company's outstanding noncallable first mortgage bonds. Various restrictive provisions in the indenture securing these bonds created additional complications. Likewise simplification by elimination of the traction company as a separate entity was impractical from a financial standpoint because of the substantial size of the traction interests. Confronted with this dilemma, the Commission granted the application, finding that the nature of the relationship of American Water Works and Electric Company to West Penn Power Company through the traction company was merely that of exercising a "controlling influence" rather than "control," and therefore the Commission had the discretion to find that the traction company and West Penn Power Company were not holding company and subsidiary.

A more difficult problem is presented when application is made for permission to create a new company which will further complicate the structure of a holding company system. Thus far cases have arisen where such creation is necessary as the sole means for raising new capital for expansion activities or as a device for liquidating certain companies which cannot ultimately be retained under Section II(b). An example of the former is Virginia East Coast Utilities ${ }^{43}$ where the applicant wished to construct additional rural electrification lines. The Rural Electrification Administration which was supplying the funds required that all loans be secured by a direct first mortgage on the property

43 I S. E. C. 887 (1936) ; Holding Company Act Release No. 475, December I4, I936. 
constructed with the proceeds of the loan. Such a mortgage the applicant itself could not give because of an after-acquired property clause in its own mortgage. Moreover, all applicant's existing first mortgage bonds and common stock were pledged under a trust indenture securing bonds of its parent company, which indenture contained a covenant not to permit any subsidiary such as the applicant to issue any additional securities of any kind unless such securities were delivered to the trustee under the indenture as further security for the parent's bonds. The simplest way to avoid these indenture provisions was to create a new company and have it issue bonds secured by a first mortgage on the property constructed with the proceeds. This procedure the Commission approved even though it added one more layer to an already complicated structure, because plans for ultimate simplification were said to be under discussion by which the new company would be absorbed. But it is interesting to note that in reaching this result the Commission approved a financing technique the use of which often has been the subject of condemnation.4t

An example of the latter situation where a new company has been created as a device for liquidating companies which ultimately cannot be retained under Section II (b) is States Electric \& Gas Corporation." A new company was organized on a "shoestring" and to it was to be transferred voting control in miscellaneous subsidiaries of the International Utilities Corporation system, located in a territory extending from New Mexico to South Carolina. This new corporation was to afford the machinery by which the system properties were to be rearranged so as to comply with Section II(b). Referring to Section IO(b) and (c), the Commission admitted that the transaction obviously was contrary to the spirit and letter of the Act if it was to be treated as the promotion of a new holding company enterprise. But since its character was essentially private and since it might be regarded as a reorganization providing for the orderly liquidation of properties in conformity with Section II, the Commission gave its approval. Here again the Commission has taken a device con-

${ }^{44}$ A somewhat comparable situation exists where a new corporation is formed and assets transferred to it to avoid the effect of negative pledge clauses in indentures. See SEC Report on Protective and Reorganization Comartitees (June 18, I936) pt. VI, at I2.

45 Holding Company Act Release No. 712, June 24, I937. 
demned in principle as bad and converted it into a means of furthering the policy of the Act. Practical considerations again were the compelling force. ${ }^{46}$

All the foregoing cases merely raise problems incidental to the elimination of unnecessary complexity in holding company systems. Only in the case of Genesee Valley Gas Company, Inc. ${ }^{47}$ has the Commission indicated a complete and satisfactory solution. The application was for approval of a plan of reorganization by the Commission prior to its submission to the bankruptcy court under former Section $77 \mathrm{~B}$. The applicant was a first degree holding company with two tiers of holding companies above it. Of its four operating subsidiaries only Pavilion Natural Gas Company was of appreciable size, representing not only most of the total property value of the combined companies but also contributing the bulk of the applicant's income. The Commission objected to the reorganization plan on several grounds but the one of interest here was the utter failure to eliminate any units from the holding company system structure so as to make it conform with the requirements of Section $\mathrm{II}(\mathrm{b}) .^{48}$ Accordingly the Commission suggested first that the applicant and the holding company above it should be dissolved, and second, that all applicant's subsidiary operating companies within the State of New York be merged into a single operating unit.

\section{Imposition of New Fiductary Concepts}

The divorcement of ownership from control in the predepression era exposed management groups to the constant temptation of permitting self-interest to outweigh their duty to the security holders. Criticism of these conflicting interests was an important factor in the enactment of the Public Utility Holding Company Act. Its provisions afford a starting point from which the Commission is proceeding to impose new fiduciary responsibilities on

46 If an application similar to that in States Electric and Gas Corporation was made to the Commission today, it is doubtful whether it would be approved. Having set December I, 1938, as the date for submission of voluntary plans to achieve compliance with $\S$ II(b), it would seem that further complication of this sort would not be permitted unless the new company was purely a liquidating vehicle.

47 Holding Company Act Release No. 981, January 24, 1938.

48 Another objection of the Commission to the plan is discussed at pp. 247-50, infra. 
the part of those participating in public utility finance and management. Already progress has been made in establishing new standards of conduct and requiring strict adherence to them.

Up to the present time these conflicts of interest have come to the Commission's attention in two types of factual situations. First, in the issuance of securities, conflicts exist by reason of the relations between managements and underwriters. Second, in reorganizations and recapitalizations conflicts arise in connection with the preparation and submission of plans altering the rights of security holders.

Conflicts of Interest in Underwriting Relations. Prior to 1935 close tie-ups between issuers of securities and underwriters were normal. Often they amounted to nothing more than an established practice of dealing with certain underwriters over a long period of years. In other instances, including the public utility field, the relation was much closer. Some holding company systems contained a separate subsidiary set up for the sole purpose of handling the underwriting arrangements for the entire system. Not infrequently underwriting firms were represented on the directorates of top holding companies. ${ }^{40}$ In such underwriting relationships the possibility of abuses when conflicts of interest were present afforded the Commission an obvious reason for exercising its supervisory authority. Consequently, the Commission has established the practice of making a detailed examination of the relationship between the issuer and the underwriters and of all relevant facts in regard to the particular issue. The objective of this examination is to make sure that no one profits at the expense of the issuer from the failure of the parties to bargain at arm's length. Hence, of particular interest are the consideration received by the issuer and the spread of the underwriters. Two cases well illustrate the nature of this examination.

In Kansas Electric Power Company, ${ }^{50}$ approval of a declaration covering the issuance of first mortgage bonds was sought by an operating subsidiary of Middle West Corporation, a registered holding company. The financing was arranged by the finance committee of an affiliated service company in the Middle West

49 UTIIITY CoRporations pt. $72 \mathrm{~A}$, at 346-48.

50 I S. E. C. 8gI (1936), Holding Company Act Release No. 486, December I9, 1936, (I937) 46 YaLE L. J. ro58. 
System and two of the committee members were in effect representatives of the principal stockholders in Middle West Corporation. In addition the head and one other member of the syndicate of seven underwriters who took the issue controlled substantial blocks of stock of Middle West Corporation. The fact that the spread of two and a half points taken by the underwriters exceeded by one quarter of a point the going rate of underwriting spreads on comparable issues brought to the Commission's attention the existing conflicts of interest in the underwriting arrangements. ${ }^{51}$ While the majority of the Commission were not prepared to say that the spread of two and a half points was unreasonable in itself, they did severely criticize the manner in which the underwriting arrangements were handled and deplored the failure to introduce any element whatever of competitive bidding. But feeling that to compel renegotiation of the loan would prove so expensive as to outweigh any saving which might be effected, the Commission by a divided vote reluctantly permitted the declaration to become effective. ${ }^{52}$

The principal significance of this phase of the case is that it raises the controversial question of the desirability of competitive bidding. Since the Commission was less concerned by the fact the underwriting spread was in its opinion about one quarter of a point too high than by " the apparent lack of effort or attempt by the management to pay less," its position clearly seems to be that it will require prices comparable to those which would result on competitive bidding. Moreover, to avoid for the future the argument that renegotiation would be too expensive, shortly after this case the Commission ruled that in all cases of issues save those sold by public competitive bidding it would require that it be notified of the underwriting spread and of any known conflicting interests of underwriters at least seven days before the declaration could become effective. ${ }^{53}$

51 This fact is not clearly brought out in the published release. The record, however, indicates that the question revolved about whether or not the spread was one quarter of a point above that on comparable issues.

52 Commissioners Healy and Douglas (now Chairman) dissented on the ground that the underwriting spread had not been justified to their satisfaction and that the entire transaction had "the familiar reek that so often attended those deals involving operating companies, holding companies, and investment bankers in earlier days." See I S. E. C. 89r, 900 (I936).

53 I S. E. C. 89 r, 897 (1936). Prior to this case the Commission had required 
Actually no statement has appeared in the releases with respect to the future necessity of competitive bidding on utility issues. The question is still open whether the Commission must go so far in order to achieve its objective. Even if the directors and officers of the issuer have some affiliation with an investment banking house, it is again doubtful, as with no-par stock and voting trusts, whether there must be a rigid and unqualified rule as long as the Commission remains empowered to rectify possible abuses. The net result to the investor, issuer and the public may be approximately the same whether the parties deal at arm's length, or conversely, whether independent negotiation was lacking but the opportunity for profit in violation of their fiduciary duty is eliminated.

That for the present the Commission has no intention of requiring competitive bidding is borne out by the second and more recent case of San Antonio Public Service Company ${ }^{54}$ where it pursued the policy of making sure that the consideration received for the securities and the fees paid were the equivalent of those which would have resulted from arm's length negotiation. An operating utility sought approval of a declaration covering first mortgage bonds with a spread of two and a quarter points and serial notes with one of one and a half points. Both blocks of securities were being sold to a group of underwriters headed by Mellon Securities Company and Dillon, Read and Co. Persons in control of the former also were substantial holders of stock in Koppers United Company, which through three subsidiaries controlled the issuer. In addition two directors of Dillon, Read and Co. were also directors of an investment trust which owned almost ro per cent of the voting securities of one of the intermediate holding companies. Again there was no element of competitive bidding such as attempted negotiations with underwriters other than the group headed by Mellon Securities Company and Dillon, Read and Co. Despite this fact the declaration was permitted to become effective, for after scrutinizing the relationship between the issuer and the underwriters, and after requiring testimony as to the justification of the spreads, the Commission was satisfied that

such information only four days prior to the proposed effective date of the declaration.

54 Holding Company Act Release No. IIo7, May 3I, I938. 
the spreads were reasonable and that the prices at which the securities were to be offered were in line with prices of substantially similar securities of public utility companies resembling the issuer. In this way the Commission felt that the results reached were equivalent to those which would ensue upon arm's length negotiation. ${ }^{55}$

Both the foregoing cases involved a standard transaction, namely, the issuance of bonds. The issuers were benefitted by being able to secure needed funds immediately. The financial advantages to the underwriters were specifically defined and were customary in such transactions. Consequently strong practical considerations influenced the Commission to permit the declarations to become effective so long as the conflicting interests had no definitely prejudicial effect. But where the transaction is not of standard character and there is no immediate benefit to the applicant company, any declaration will be viewed with suspicion, especially when it appears probable that the only advantage to be derived will be that of an underwriter with whom the declarant has intimate ties. This was the case in Northern States Power Company ${ }^{56}$ where six months after an issue of preferred stock had been sold to underwriters, the issuer sought approval of a declaration which made that preferred stock convertible into common and which reimbursed the preferred stockholders for the Pennsylvania five-mill tax. At that time the price of the stock had fallen off about twenty points and the underwriters still had on their shelves one quarter of the issue. The Commission felt the

55 Similar holdings of the Commission are to be found in Gulf States Utilities Company, Holding Company Act Release No. I228, August 3I, 1938, and American Light \& Traction Company, Holding Company Act Release No. 1272, October I4, 1938. The latter case was commented upon in note 7 , supra, as an application for exemption under $\S 6(\mathrm{~b})$.

Closely related to the problem of achieving fair dealings between issuer and underwriter is the question of the "finder's fee" charged in some cases by an affiliate of the issuer for negotiating a private offering of securities to purchasers such as banks and insurance companies. In each of the two cases before the Commission thus far where such a fee has been claimed, the issue of the securities has been approved and jurisdiction reserved with respect to the reasonableness of the fee. West Penn Power Company, Holding Company Act Release No. 1207, August 15, I938; North American Edison Company, Holding Company Act Release No. I30r, November 2, I938.

${ }^{56}$ Holding Company Act Release No. 874, November 8, 1937, (I938) 38 Cor. L. REv. 5 Ix. 
only persons who would derive any benefit from approval of the declaration would be the underwriters and consequently made the adverse finding under Section $\bar{\gamma}(\mathrm{d})(3)$ that the proposed changes were not necessary or appropriate to economical and efficient operation of the declarant's business. While the Commission stated that this adverse finding was made without deciding whether it would be proper to give any consideration to the close relationship which existed between certain of the principal underwriters and the issuer, at the same time it admitted that this situation made it particularly careful in deciding whether the declaration met the statutory standards imposed by Section 7 .

Conflicts of Interest in Reorganizations. Nowhere do conflicts of interest appear so frequently as in reorganizations. Their presence is manifest throughout the process of both voluntary and judicial reorganizations. Consequently, reorganization practice in the past has been far from ideal. Voluntary plans favoring common stock interests have been formulated by the management and "railroaded" through without affording other security holders an opportunity to understand how their interests were affected. In judicial reorganizations severe criticism has been directed at the almost ruthless disregard of rights of senior claimants by dominant management and banking interests. Such criticism was partially responsible for the recent enactment of Chapter $X$ of the new Bankruptcy Act, commonly known as the Chandler Act, to replace former Section $77 \mathrm{~B}^{57}$

The Public Utility Holding Company Act seeks to minimize these conflicts of interest by administrative supervision designed to reform the machinery by which plans of reorganization are consummated. Approval by the Commission of plans under court supervision is specifically required by Section I I (f). A like result ensues in voluntary reorganizations, for although the Commission is not empowered to pass on a plan as such, the applications required under Sections 6, 7, ro or II (g), as the case may be, give the Commission a power not in terms but in fact comparable to that under Section II (f).$^{58}$

57 Pub. L. No. 696, 75th Cong., 3d Sess., II U. S. C. A. \$\$ 50I-676 (Supp. 1938); see Gerdes, Corporate Reorganizations: Changes Effected by Chapter $X$ of the Bankruptcy Act (I938) 52 HARv. L. REv. I.

58 The Commission has beld that where a plan of reorganization contemplates the issuance of securities and the acquisition of utility assets and securities, the standards prescribed by $\S \S 7$ and ro must be complied with. United Telephone and 
More specifically, under the Act the Commission is endeavoring to accomplish certain objectives:

(I) To set forth the parties eligible to submit a plan of reorganization and to require disclosure of the interests they represent;

(2) To encourage independent representation of each class of security holders by representatives who have only the interest of their own class at heart;

(3) To afford security holders full information as to how the plan affects their rights so as to enable them to assent or dissent intelligently;

(4) To ensure that the plan, before its submission to security holders, conforms with the Commission's standards of fairness;

(5) To regulate and impose fiduciary responsibility upon persons soliciting proxies or acceptances, whether a committee or otherwise.

The eligibility of persons to submit a plan in either a voluntary or judicial reorganization is restricted to those having a " bona fide interest." 59 If the Commission had wished to ensure the exclusion of management from participation in the plan, this restriction might have been found a useful instrument. In fact, Chairman Douglas (then Commissioner) raised a query as to this precise point in International Paper and Power Company ${ }^{60}$ in stating his objection to the lack of independent representation of the preferred stock in formulating a recapitalization plan. The Commission's present definition of eligibility, however, is extremely lenient, including among others the company, or any creditor or stockholder thereof, and as yet no party has been excluded from offering his plan of reorganization. ${ }^{61}$

Electric Company, Holding Company Act Release No. Ir87, August 5, I938; West Ohio Gas Company, Holding Company Act Release No. I284, October 22, 1938; Peoples Light and Power Company, Holding Company Act Release No. 885, November I6, I937 (concurring opinion of Commissioner Healy). The Commission has also held that the question of fairness of a plan of reorganization is before it under $\S 7$. International Paper and Power Company, Holding Company Act Release No. 77o, August 3, I937. See also Rule IIF-I (d), General Rules and Regulations under the Public Utility Holding Company Act of 1935 , as amended, to and including July $\mathrm{r}, \mathrm{I} 938$.

$59 \S \operatorname{II}(\mathrm{g})(\mathrm{I})$.

60 Holding Company Act Release No. 642, May 5, I937, at p. 9.

o1 Rule I2E-I (d), General Rules and Regulations under the Public Utility Holding Company Act of 1935 , as amended, to and including July I, 1938 . 
After the enactment of Chapter X of the new Bankruptcy Act, all persons having a " bona fide interest" are still eligible to submit plans. But they cannot do so in the early stages of the proceedings. The newly prescribed procedure of Chapter $\mathrm{X}$ requires the appointment of a disinterested trustee in all cases where the corporate indebtedness exceeds $\$ 250,000$ and makes him responsible for the preparation of the original plan and its submission to the court. ${ }^{62}$ This centralization of authority in a trustee totally devoid of any commitments supplements the Commission's program of insulating the reorganization from domination by any special group, such as management. Even before Chapter $\mathrm{X}$ became law, the Commission initiated this policy by filing a brief amicus curiae in the reorganization proceedings of Utilities Power and Light Company, requesting the appointment of an independent trustee as essential to the proper solution of the debtor's problems.

The second objective of the Commission is to stimulate greater participation by security holders in the reorganization process through their own independent representatives. In bankruptcy reorganizations Chapter $\mathbf{X}$ of the new Bankruptcy Act does much to bring closer its achievement. Accurate information concerning the condition of the company is made available to interested parties by imposing on the independent trustee the duties of making an investigation and submitting a statement of his findings. ${ }^{63}$ Lists of security holders, even though in possession of persons other than the debtor or its indenture trustee, are made accessible to all. Thus encouraged perhaps more parties will participate, especially since compensation for their efforts is possible from the debtor's estate. ${ }^{64}$

At the same time, whether the reorganization is voluntary or involuntary, the Commission is prepared to insist that the parties

62 Pub. L. No. 696, 75th Cong., 3d Sess. § 156, II U. S. C. A. $\$ 556$ (Supp. 1938). However, this provision would not seem to preclude the Commission from proposing a plan in the first instance as it is specifically empowered to do so for bankrupt companies in the public utility field by $\S$ II(f) of the Public Utility Holding Company Act.

63 Id. $\S 167(x),(5)$, Ix U. S. C. A. $\S 562$ (x) (5) (Supp. I938).

${ }^{64}$ Id. $\$ \S 242,243,246$, II U. S. C. A. $\$ \S 642,643,646$ (Supp. I938). However, even if greater participation by security holders does ensue, a perhaps over-optimistic anticipation, it possibly may be largely of the "strike suit" variety. 
participating shall act as representatives of only one class of security holders. In Utilities Power and Light Corporation, ${ }^{65}$ three individuals purporting to be a protective committee representing debentures, preferred, class $\mathrm{A}$, class $\mathrm{B}$, and common stock of the corporation being reorganized, filed a petition to intervene in the proceedings before the Commission. The Commission felt it was clear the committee was connected with Associated Gas \& Electric Company interests and had been organized on their behalf. Consequently, there was reason to suppose that the committee's activities would be dominated by Associated interests and independent representation would not be provided for the various securities. However, the Commission was anxious to assure representation of all points of view in the proceedings and the committee did seem to have authorizations from a substantial number of security holders. Accordingly, the intervention was permitted, subject to the conditions that any evidence adduced by the committee would be weighed in the light of the conflicting interests present and that any communications to security holders should be accompanied by a copy of the Commission's opinion.

In voluntary reorganizations the problem of stimulating greater participation by security holders in preparation of plans is more acute. $^{66}$ The exigency confronting the security holders is not as clear-cut as in bankruptcy nor does the revision appear as drastic. No disinterested trustee is charged with the preparation of the plan or of presenting facts to them. Investors other than the management group are usually without the funds necessary to participate and there is no incentive by way of possible compensation from the estate. Indeed, probably no plan would be forthcoming at all if management did not take the initiative. Consequently, the Commission's greatest problem lies in overcoming the inertia of security holders. An example of this dilemma is found in International Paper and Power Company. ${ }^{67}$ A recapitalization plan was proposed altering the rights of preferred stockholders and eliminating a capital deficit, thus opening the way for both preferred and common dividends to avoid the tax on undistributed

65 Holding Company Act Release No. 1245, September 2I, I938.

go SEC Report on Protective and Reorganization Commitees (May ro, I938) pt. VII, § I.

67 Holding Company Act Releases Nos. 64I and 642, May 5, 1937. 
profits. The plan was prepared by a committee composed of representatives of both common and preferred stocks, yet those committee members representing preferred stock for the most part also held common. ${ }^{88}$ Consequently their position was somewhat "neutralized" and the preferred stockholders were left without representatives whose loyalty ran exclusively to their own class. From the Commission's report under Section II (g) which accompanied the solicitation of proxies approving or disapproving the plan, it seems the majority were not sure whether the plan was fair to the preferred stockholders or not but that they were willing to permit it to be voted upon. In view of the peculiar quorum provisions for stockholders' meetings, the majority especially urged upon the stockholders the necessity of affirmatively voting against the plan if they disapproved of it. ${ }^{69}$ Commissioner Healy in his dissent, which also went to the stockholders, felt very strongly that the plan was unfair to the preferred stockholders and urged them to fill out their proxies marked "No." 70 At the stockholders' meeting which then ensued over 77 per cent of the preferred stockholders were represented and of these $9 \mathrm{I}$ per cent voted in favor of the plan. ${ }^{71}$ This does seem to have been a large representation, but nevertheless, the fact remains that in the face of a rather striking report by the Commission over 22 per cent of the preferred stockholders made no effort to vote. This may be some evidence of the inertia of security holders which the Commission must overcome if its policy of bringing about greater participation in reorganizations is to be successful. Indeed it opens to question the feasibility of the policy itself. ${ }^{2}$

68 Holding Company Act Release No. 64I, May 5, I937, p. 6.

69 Under the quorum provisions if one-third of the outstanding shares, regardless of class, were represented at a meeting, a quorum was present. There were two classes of preferred stock and three of common. Consequently, merely withholding a proxy would hardly be an effective dissent.

70 Holding Company Act Release No. 64I, May 5, I937, pp. I8-22.

71 Holding Company Act Release No. 770, August 3, I937.

72 Of course this silence is ambiguous. Perhaps these $22 \%$ of the preferred stockholders liked the plan and felt it was unnecessary to vote.

In some cases it does not seem unlikely but that the policy of bringing all facts to the attention of the security holders may discourage rather than encourage greater participation of security holders. For example, the ballots which were sent out in the American Gas and Power Company case, discussed at p. 252, infra, together with the Commission's report on the plan and other data, were so complicated as to dishearten any but the most persistent of security holders. 
Whether or not the parties act affirmatively on the basis of information afforded them, the Commission at least has accomplished its objective of bringing to their attention the purpose of the plan, its precise character and the alternatives available, together with a description of its sponsors. Irrespective of the character of a reorganization, solicitation of any consents thereto is made unlawful by Section II (g) unless the plan is first submitted to the Commission together with adequate information regarding it and its sponsors. This information is then conveyed to the security holders in the report on the plan by the Commission which must accompany or precede the solicitation. ${ }^{73}$ The International Paper and Power Company case is an illustration of this procedure.

As noted above, in practical effect the Commission passes upon both judicial and voluntary plans of reorganization. In such cases the question of fairness of the allocation of new securities is before it under Section 7. But as a preliminary to determining fairness it is necessary to value a company's property. In making such valuations the Commission early committed itself to the policy that earning power should be the paramount criterion. At the same time it has always carefully analyzed a company's property account to ascertain the value at which assets were taken on the books so as to eliminate any write-ups. Finally, it has manifested its unwillingness to accept reproduction cost as a true measure of value. ${ }^{74}$

Up to the present time the question of fairness has been considered by the Commission in five cases, two voluntary and three under former Section 77B. In Genesee Valley Gas Company, Inc. ${ }^{75}$ under Section ${ }_{77} \mathrm{~B}$, the Commission indicated that in ascertaining the fairness of a plan it would look to the established precedents of the courts, whether in equity or under the Bankruptcy Act. Thus at the outset it has raised the question of whether it will adopt the theory of strict priority growing out of the doctrine of the Boyd case. ${ }^{76}$ In the Genesee case the Commission indicated

73 II (g) (2). See also the new Bankruptcy Act, Pub. L. No. 696, 75th Cong., 3 d Sess., $\S \S$ I75, I76, II U. S. C. A. $\$ \S 575,576$ (Supp. I938).

74 Genesee Valley Gas Company, Inc., Holding Company Act Release No. 981, January 24, I938; West Ohio Gas Company, Holding Company Act Release No. 1284 , October 22, I938.

75 Holding Company Act Release No. 98I, January 24, I938, (I938) 38 Cor. L. REv. 680 .

76 Northern Pacific Ry. v. Boyd, 228 U. S. 482 (I9I3). For discussion of the 
a preference for this view. The focal point of the reorganization was Pavilion Natural Gas Company, a single operating subsidiary from which almost the entire income of the system was derived. This company had been supporting a superstructure of three layers of holding companies and the plan contemplated no immediate change in this respect. As to Genesee Natural Gas Company, Pavilion's immediate holding company, the plan left the mortgage bonds untouched and allocated thirty-seven thousand odd shares of new stock among creditors and noteholders, with 739 shares going to the old stock interests. Among the several grounds on which the Commission opposed the plan was the finding that Genesee's earning power did not justify the new capitalization and particularly did not warrant any participation in the reorganization by the old stock. In view of the almost negligible participation of the old stock, the Commission's opinion on this point, even though affected by the question of voting power, would seem to show a tendency toward a policy of strict maintenance of priorities. ${ }^{77}$

Although the field of voluntary reorganizations is not circumscribed by judicial precedents to the same extent as that of reorganizations under court supervision, ${ }^{78}$ there is some indication in the Commission's opinions that the policy of strict priority will play a part there as well. This policy apparently motivated Commissioner Healy's dissent in International Paper and Power Company, ${ }^{79}$ an opinion which may have greater significance in view of subsequent developments in that case and the changed personnel of the Commission. ${ }^{80}$ Analyzing the recapitalization plan, the

so-called strict and relative theories of priority, see Bonbright and Bergerman, $T$ wo Rival Theories of Priority Rights of Security Holders in Corporate Reorganization (x928) 28 Col. L. Rev. I27; Fintetter, Princtples of Corporate Reorganization (I937) c. VI; (I938) 38 CoL. L. REv. 680 (commenting specifically on the Genesee case).

77 The question of voting power in this case is discussed at p. 250, infra.

78 There are some precedents. For example, the rule against wiping out by charter amendment accumulated dividends protects the priority of preferred stockholders in a fashion similar to the doctrine of the Boyd case. Cf. Keller v. Wilson \& Co., I9o Atl. II5 (Del. I936).

79 Holding Company Act Release No. 64r, May 5, 1937, pp. I8-22.

80 This case has had a long and involved history. With some misgivings the Commission took jurisdiction of the case on May 5, I937. Chairman Landis, Commissioners Ross, Mathews and Douglas were in favor of taking jurisdiction; Commissioner Healy opposed it. At the same time Commissioner Healy also dissented to the report on the plan and Commissioner Douglas indicated his dislike of certain 
Commissioner arrived at a valuation both from the standpoint of book value and earnings which, in his judgment, made two of the three classes of common stock worth less than nothing. Though in this dissent there is no reference to precedent in determining fairness, it is interesting to note a theory developing which resembles the doctrine of the Boyd case. It is especially interesting in the area of recapitalizations where the bargain, as here, is usually between two classes of stock, rather than between creditors and stockholders. Yet if priority is to be given creditors and in view of the Commission's tendency to insure that preference features and voting rights of preferred stocks are not illusory, it would not be surprising for the Commission to protect preferred stocks in recapitalizations and in reorganizations where any equity remains for stock interests. But at the same time it is to be expected that the Commission will not permit this policy to grow to such a proportion in voluntary reorganizations that it will interfere with its program of simplification of corporate structures.

The apparent strictness of the Commission policy indicated above has been tempered in United Telephone and Electric Company, ${ }^{81}$ and to a lesser extent in West Ohio Gas Company. ${ }^{82}$ In fact, in the former its relative indifference to the distribution of a small amount of common shares to old stockholders raises some doubt of consistency with the Genesee case. United Telephone

features. On August 3, I937 (date of release), the Commission exempted the securities to be issued pursuant to the plan, Chairman Landis and Commissioner Mathews voting for the exemption, Commissioner Douglas against it. Holding Company Act Release No. 770.

In September, I937, a common stockholder named Lawless applied to the Commission for a rehearing. On October 13, 1937, the Commission, acting through Chairman Douglas and Commissioners Mathews and Healy, denied the application. At that time Mr. Landis was no longer a member of the Commission and Commissioner Ross had not heard the argument on the application. Holding Company Act Release No. 850. In this opinion it was indicated that if the case had been up for the first time, the exemption would not have been granted.

The final chapter in the case remains to be written. On September Ix, I937, Lawless filed a petition for review of the Commission's order of August 3, I937 (release date), with the United States Circuit Court of Appeals for the First Circuit. The fact that this attack came from a common stockholder would at least indicate the wide range of controversy with respect to the fairness of the plan.

81 Holding Company Act Release No. II87, August 5, I938.

82 Holding Company Act Release No. 1284, October 22, I938. 
and Electric Company involved a reorganization plan under former Section $77 \mathrm{~B}$. In passing on the question of participation of the old common stockholders the Commission noted that even on the basis of valuation claimed by the reorganization managers, the new securities issued to the holders of the preferred shares did not equal the amount of claims upon them. The prospective earnings of the new company also fell far short of the requirements for dividends on the old preferred. However, the Commission concluded that "the relatively insignificant portion of the equity allocated to the common," 2.82 per cent, did not appear to infringe "unfairly upon the contract rights and priorities of any class of stockholders or creditors," and approved the plan.

There are several bases for distinguishing the United Telephone case from the Genesee case. In the first place the parties who suffered any loss of priority were preferred stockholders rather than creditor claimants. Secondly, the Commission noted that a substantial amount of common stock was held by operating employees of the company's subsidiaries whose participation in the plan would create an element of good will which might be of importance to the senior security holders. But the fundamental distinction between the two appears to be control, an element which has assumed major significance in the Commission's consideration of reorganization plans. It is an interesting speculation whether in the Genesee case the Commission would have adopted a policy of strict priority if the distribution of shares had not affected control of the newly reorganized company. Out of some thirtyseven thousand shares, only 739 were to go to old stockholders, an amount smaller upon a percentage basis than the 2.82 per cent which the Commission deemed a " relatively insignificant portion of the equity" in United Telephone. But in the Genesee case, on the basis of the exchange proposed in the plan, 5 I.4 per cent of the voting control would be in the hands of the present management and 48.6 per cent with the public; so that 739 shares, representing roughly 2 per cent of the stock, would theoretically be able to swing control either way.

In West Ohio Gas Company, ${ }^{83}$ involving reorganization of an operating company under former Section $77 \mathrm{~B}$, the old bondholders were to receive under the plan half of the principal amount of

83 Holding Company Act Release No. 1284 , October 22, 1938. 
their old bonds in new bonds and over 90 per cent of the new common stock. The parent of the bankrupt, by virtue of its ownership of certain notes and $5^{2}$ per cent of the old preferred stock, was to receive over 8 per cent of the new common stock and the balance went to other holders of the old preferred. The old common stock was wiped out entirely by the plan. Once again the evidence pointed to the conclusion that the bankrupt's property had little, if any, value in excess of the claims of the old bondholders, thereby raising the question of the propriety of participation by junior creditors and stockholders. Here again, as in United Telephone and Electric Company, the Commission declared that " the relatively small participation by the unsecured creditors and preferred stockholders" did not amount to such a substantial diversion of interests belonging to the bondholders as to require a finding that the plan was unfair. Even though the value of the property in this case was affected by certain contingencies as to future earnings which are not to be found in the ordinary case, ${ }^{84}$ the decision definitely points to the conclusion that the Boyd case doctrine will be applied reasonably rather than strictly.

West Ohio Gas Company has additional significance in another respect. The Commission placed itself on record on the question of whether under the Boyd case doctrine priorities must be so maintained that the same grade of new securities cannot be offered to security holders of different rank. Following the United States Supreme Court ${ }^{85}$ the Commission held that a variation in amount of the new securities, even though of the same grade, was a sufficient recognition of priorities, and permitted the noteholder and the preferred stockholders to share in the common stock with the old bondholders. ${ }^{86}$ That such a result is necessary on sheer grounds of policy seems apparent, for otherwise the objective of the Act to simplify corporate structures and securities would be rendered wholly unrealizable.

The importance of control as an element in determining fairness

84 These contingencies included an upturn in business attributable to an aggressive merchandising campaign and an effort to improve public relations. See Holding Company Act Release No. I284, October 22, I938, p. 6.

85 See Kansas City Terminal Ry. v. Central Union Trust Co., 27 I U. S. 445 (Ig26).

86 Commissioner Healy, while concurring in result, did not concur in the majority's application of this case. 
arose again in American Gas and Power Company. ${ }^{87}$ Although some courts have expressed concern as to control of newly reorganized companies, there has been no clear-cut recognition that the history of a management in the past was a fair criterion of its performance in the future. The plan for Birmingham Gas Company was proposed jointly with its parent, American Gas and Power Company. By reason of the additional cash consideration tendered by the parent, and the lack of information with respect to the valuation of Birmingham's property, it is impossible to arrive at any satisfactory conclusion as to the fairness of the distribution of securities under the plan. However, examination of

87 Holding Company Act Release No. I256, September 30, 1938. The recapitalization plan of Birmingham Gas Company came before the Commission as part of a joint application by it and its parent, American Gas and Power Company, under $\S \S \mathrm{II}(\mathrm{g}), \mathrm{I}_{2}(\mathrm{c})$ and 7 of the Act. The background of the recapitalization and the terms of the plan are extremely complicated but are necessary to an understanding of the case.

Reduced to a bare minimum, the difficulties mainly revolved around an obligation of American to Birmingham for $\$ 1,105,000$, created in 1932. Under the proposed plan Birmingham was to cancel this obligation in return for $\$ 550,000$ in cash, the cancellation of a note of Birmingham held by American for $\$ 405,000$, and the return to Birmingham of 60,000 shares of its common stock held by American. American was to retain its controlling interest in Birmingham's common stock. If the obligation of $\$ \mathrm{I}, \mathrm{I0}, 000$ of American had been of standard character, the plan would have been discriminatory against Birmingham, even without reference to American's retention of Birmingham's common stock (which might be wiped out had the companies been forced into a bankruptcy reorganization). However, the obligation was not of standard character. It arose in I932 out of an investigation by the Alabama Public Service Commission of intercompany transactions between American and Birmingham. At that time the Alabama Commission fixed the indebtedness of American to Birmingham at $\$ 1,105,000$, which American agreed to pay pro rata with other unsecured debt out of earnings in excess of operating expenses and fixed charges. No definite maturity for the note was prescribed.

In 1935 American was reorganized under former $\$ 77 \mathrm{~B}$ of the Bankruptcy Act under a plan that gave substantial participation to old stockholders of American despite diminution of claims of Birmingham and other subsidiaries, which at that time were creditors of American. Their consents to the plan were filed by counsel for American rather than through independent representatives, and the $\$ 1,105,000$ obligation was converted into a form of income note without maturity. Payments of interest and principal on the note were limited to a certain fraction of the net earnings of American as computed in a formula set forth in the plan. This formula, as construed by counsel for American, was of such a nature that by continued bank borrowing and repayment, distribution to Birmingham under the formula could be avoided. This construction was reached on the theory that repayments of such bank loans were "interest and sinking fund installments" which constituted a deduction before computing " available net earnings."

However, the Commission found Birmingham's recapitalization plan "was not 
earlier financial transactions between the two companies by the Commission disclosed a "long record of spoliation" of Birmingham by its parent. This was regarded by the Commission as justifiable reason for imposing conditions upon the consummation of the plan.

So far as fairness of plans is concerned, the opinion indicates two tendencies of the Commission. First, while it recognizes that nothing is to be done about the past per se, nevertheless it will make extensive use of the record of a company to correct what it deems earlier injustices to the extent it reasonably can do so in the particular case. Secondly, the case indicates that by imposing terms and conditions the Commission may substantially modify plans of reorganization without assuming the status of a proponent of a plan. In addition the case raises an interesting question of Commission procedure in passing upon voluntary plans. As in International Paper and Power Company, also involving a voluntary recapitalization, ${ }^{88}$ the Commission was not certain in its own mind as to the fairness of the plan, but nevertheless found it "not so unfair" that it felt it would not be justified in denying the security holders an opportunity to vote upon the plan. Whether or not the Commission will ever adopt the same policy in judicial reorganizations where Section II(f) expressly requires it to approve the plan of reorganization still remains undetermined.

To complete the process of insulation from the dominance of a single group, such as management, solicitations are required to conform with such rules and regulations as the Commission may

so unfair that the declarations under Section 7 (d) may not be permitted to become effective." But certain conditions were imposed, the most important of which roughly are as follows: (I) No deduction of interest and amortization payments on American's bank loans could be made under the formula without express consent of the parties affected, and failing such consent a prior deduction of $\$ 100,000$ was to be restored to available net earnings. (2) The plan must be approved by large percentages of the parties affected, varying from $66 \frac{2}{3} \%$ in the case of American's secured debentures to $95 \%$ in the case of Birmingham's preferred stock. This approval must be after such security holders received the report of the Commission on the plan and all solicitation literature had been passed upon by the Commission. (3) Birmingham and other subsidiaries in a like situation should retain independent counsel to advise them with respect to intercompany transactions. (4) The Commission should retain continuous jurisdiction with respect to fees and expenses paid in connection with the plan, and to the application of funds by American until its bank loan is repaid.

${ }^{88}$ See p. 245 , supra. 
deem necessary. Pursuant to its authority under Sections II ( $g$ ) (3) and I2 (e), the Commission has issued certain rules which, in addition to providing the investor with adequate information concerning his solicitor and the expenses involved, drastically alter the scope of authority of those soliciting and tend to impose upon them fiduciary responsibilities. ${ }^{89}$

The effect of these rules is well illustrated in the recent release In the Matter of John A. Dawson ${ }^{90}$ where certain individuals sought permission to act as a protective committee and to solicit the deposit of bonds in the reorganization under former Section ${ }_{77} \mathrm{~B}$ of a subsidiary of Utilities Power \& Light Corporation. The deposit agreement, pursuant to which solicitations were to be sought, contained many provisions which proved to be directly contrary to the Commission's standards. Under it a depositing bondholder surrendered all vestige of control over his bonds and virtually gave the committee a " blank check" to act as it pleased. The privilege of withdrawal from the agreement was extremely limited, being conditioned on a bondholder's paying his pro rata share of the expenses of the committee as determined by the committee. The committee was to have power to trade in deposit certificates and in securities of the company, and at the same time was exonerated from all liability except for gross negligence or wilful default.

All these provisions were severely condemned by the Commission in its opinion refusing to permit the committee to act, for they were in direct contravention of the rules which had been issued under Section I2(e). The "blank check" clause ran counter to the established policy of the Act of offering each security holder adequate information and opportunity to exercise his own judgment as to whether to accept or dissent from the plan. ${ }^{91}$ The restricted privilege of withdrawal directly violated Rule U-I2E-3 requiring provision for an unconditional right of withdrawal at any time before the authorization was conclusively exercised. ${ }^{92}$

89 Rules U-r2E-I, 2, 3, 4, 5 and 6, General Rules and Regulations under the Public Utility Holding Company Act of $\mathbf{1 9 3 5}$, as amended to and including July $\mathrm{I}$, I938.

90 Holding Company Act Release No. 1200 , August 18, I938.

$91 \S \operatorname{II}(g)$. See also the new Bankruptcy Act, Pub. L. No. 696, 75th Cong., 3d Sess. $\S \S$ I75, I 76 , II U. S. C. A. $\$ \S 575,576$ (Supp. I938).

92 It should be noted that Rule U-ז2E-3(c), (d) of the General Rules and 
Moreover, since the committee was undertaking to act in a fiduciary capacity, the power to determine its own expense, to trade in deposit certificates and in securities of the company, and the exoneration from liability were considered thoroughly inconsistent with the proper responsibilities of a trustee. ${ }^{93}$ Consequently, the Commission found the deposit agreement failed to measure up to the desired standard of fiduciary duty.

Conflicts of Interest in Corporate Trustees. In the so-called Barkley Bill ${ }^{94}$ introduced in the recent Congress, extensive changes were contemplated in the position of the corporate trustee. The general policy is to make trustees under indentures truly trustees with fiduciary responsibilities toward the security holders rather than mere "stakeholders." That this same policy will be carried out under the Public Utility Holding Company Act wherever possible is a foregone conclusion, for such a policy is directly in line with the program of encouraging independent representation of each class of security holders under all circumstances. A striking example of this policy is found in Kansas Electric Power Company. ${ }^{95}$ The declarant was seeking approval of the issuance of $\$ 5,000,000$ of first mortgage bonds, secured by an indenture to a corporate trustee which at that time was the largest single stockholder of the company's parent. This gave rise to an obvious conflict of interest on the part of the corporate trustee. However, the declaration was permitted to become effective by a divided vote of the Commission. Both the majority and the dissent were agreed as a matter of principle that independence of the corporate trustee was essential not only at time of default when it would have to act to protect the bondholders, but also at

Regulations under the Public Utility Holding Company Act of 1935 , distinguishes sharply between a solicitation of restricted authorizations or proxies merely to represent security holders in negotiating a reorganization plan and a solicitation of consents or dissents to a plan. Every restricted authorization must expressly state it does not constitute a consent or dissent, while every solicitation of consents or dissents must be preceded or accompanied by a copy of a report made by the Commission, together with adequate disclosure of the interests and compensation of the soliciting parties.

93 See SEC Report on Protective and Reorgantzation Comamtrees (May ro, I937) pt. I, pp. 888-96.

o4 S. 2344, 75th Cong., 3d Sess. (1938).

85 I S. E. C. 89I (I936), Holding Company Act Release No. 486, December I9, r936, (1937) 46 YALE L. J. I058. The case is also discussed at p. 238, supro. 
the time the trust indenture was drafted. But the majority felt that since the stock ownership of the corporate trustee was temporary in nature and since to compel the renegotiation of the issue and selection of a new corporate trustee would result in unnecessary expense to the issuer, no adverse action should be taken. Commissioners Healy and Douglas dissented saying: " The opportunity for negotiation with an eye single to the interests of the bondholders has passed." ${ }^{96}$ Nowhere, however, does the dissent point out any particular provisions in the indenture that should not have been there nor the omission of any provisions which should have been included. ${ }^{97}$

Admittedly the factual situation above was a novel one and is not likely to reoccur. But since the division of opinion was largely on a question of expediency in the light of circumstances of a particular case, the opinion may be regarded as an accurate statement of the policy of the Commission to require wholly independent corporate trustees who at the time of negotiation of trust indentures will act to secure the most protection for their security holders.

Another aspect of the problem of conflict of interest in corporate trustees arose very recently in Indiana General Service Company. ${ }^{98}$ An operating company, organized in Indiana, proposed to issue first mortgage bonds with the Guaranty Trust Company of New York as trustee under the indenture. The issuance had been authorized by the Public Service Commission of Indiana and since it was for the purpose of financing its business as a public utility company, the issuer sought exemption under Section 6(b) from filing a declaration under Section 7. The Guaranty Trust Company, however, was already trustee of a debenture issue of the applicant's parent company. The Commission's opinion states that the Guaranty Trust Company represented that it would resign within sixty days as trustee of the proposed issue unless the Commission found that no substantial conflict of interest existed.

96 I S. E. C. 891, 899 (1936), Holding Company Act Release No. 486, December I4, I937, at p. 7 .

97 Immediately after approval of the declaration, the corporate trustee resigned as trustee under the indenture securing the bonds involved in the declaration, and also as corporate trustee under two other indentures where it was in the same position.

98 Holding Company Act Release No. 1261, October 5, 1938. 
While no condition in this regard was attached to the order granting the exemption, the inference is that this representation was required by the Commission before the order was granted. If the Commission adopts the policy of forbidding the same trust company to act as corporate trustee under more than one indenture of companies occupying a relation of parent and subsidiary, this policy, while perhaps consistent with the objective of the Barkley Bill, will go farther than the provisions of any draft of that bill proposed to date.

\section{CONCLUSION}

Appraising the work of the Commission as a whole, it is clear that though the "death sentence "provisions of Section II overshadow all others in the public eye, no policy has yet been defined with respect to simplification and integration of holding company systems beyond recognizing the essentially evolutionary character of the process. But in passing on applications in regard to security issues and plans of reorganization, certain standards for public utility finance and management have been imposed. To many practicing lawyers and financial advisers this aspect of the Commission's work is of paramount interest.

To such persons one important question is whether in imposing standards the Commission has pursued a moderate course or gone to the extreme limits made possible by the broad language of the Act. From what has been said heretofore it should be apparent that in most instances the Commission has adopted a policy of moderation. The standards it has applied for the most part are not new standards of its own creation but standards which had been recognized as good corporate practice prior to passage of the Act. The essential difference today is that imposition of these standards by the Commission to all companies and persons subject to its jurisdiction has greatly expanded their field of application and in so doing has raised the general level of corporate practice.

A second question of like nature is whether in imposing these standards the Commission has been able to make them flexible rather than rigid. Like any other administrative body, the Commission might have tended to "freeze" its practice within narrow 
boundaries. Fortunately, it has recognized its role as an administrative body and not a court, and the dangers of inelasticity have largely been avoided. There has been no dogmatic prohibition of voting trusts and no-par stock, no rigorous requirement of competitive bidding upon the sale of new issues nor of absolute priority among classes on reorganization. Since the possibility of harm from devices of this type lies solely in the way they are used, the Commission has realized that its continuing jurisdiction over utility companies, enabling it to deal with each problem on its own facts, will afford adequate protection. But in some instances the Commission has found it desirable to set up less flexible standards. Where the greatest possibility of abuse exists at the inception of a transaction, as with the initial distribution of voting power, adherence to more stringent standards has been required. But on the whole the elasticity of Commission policy has been a marked characteristic of its administration of the Act. At the same time the Commission has made clear in every case its unwillingness to compromise its final objectives of simplifying corporate structures and securities and of eliminating profits arising from failure to recognize fiduciary responsibilities.

John F. Meck.

William L. Cary.

YaLE School of LAW.

WASHINGTON, D. C. 